\title{
Integrating the Carrying Capacity Methodology into Tourism Strategic Plans: A Sustainable Approach to Tourism
}

\author{
Selena Candia*, Francesca Pirlone, Ilenia Spadaro \\ DICCA Department of Civil, Chemical and Environmental Engineering, Genoa University, Via Balbi 5, 16126 Genova, Italy
}

Corresponding Author Email: selenacandia@hotmail.it

https://doi.org/10.18280/ijsdp.150317

Received: 12 March 2019

Accepted: 16 December 2019

\section{Keywords: \\ tourism planning, tourism carrying \\ capacity, tourism strategic plan}

\begin{abstract}
Tourism and sustainable development are closely related to each other. In 2015, the United Nation established the 2030 Agenda for Sustainable Development along with the sustainable development goals for the coming years. Sustainable tourism plays a direct or indirect role in achieving some of these goals, enhancing social equity, economic efficiency and environmental responsibility. All other forms of tourism are the opposite of any definition of sustainable development. For this reason, the paper proposes an innovative methodology helping local administrations manage tourism in a sustainable way. The idea is to integrate the calculation of the tourism carrying capacity -the maximum number of tourists that can visit, at the same time, a destination without causing negative impacts- in Tourism Strategic Plans. The authors' research interests focus on the Mediterranean region, which is famous to be the first tourist destination in the world. Sustainable tourism can contribute significantly to the economic development of local communities without creating negative impacts on the physical, social and cultural environment of a tourist destination. The carrying capacity methodology was designed to avoid these negative impacts and to support tourism sustainable development. The paper suggests that policy makers and urban planners calculate the carrying capacity of the main tourist attractions in their region. Once calculated, the authors propose different solutions/actions to be included in Tourism Strategic Plans depending on whether the carrying capacity is greater, less or equal to the actual number of tourists who visit a destination daily. This innovative approach should be integrated in all Tourism Strategic Plans in the Mediterranean area. The authors analyse a case study - the Liguria Region - to make the carrying capacity assessment more concrete giving guidance to local authorities all over the world.
\end{abstract}

\section{INTRODUCTION}

The tourism sector is becoming increasingly important within spatial planning. Many national and local authorities are adopting new measures to manage visitor flows and to make the most of the tourism industry. In the last decades, the tourism sector has experienced continuous growth. This industry generates the $10 \%$ of world's GDP, the $7 \%$ of global trade and one in 10 jobs. In 2017, the UNWTO -United Nations World Tourism Organization- registered a new record in international tourism: international tourist arrivals grew for the eighth consecutive year and destinations worldwide hosted 84 million tourists more than in 2016. That is why is not surprising that tourism management is a key priority for several Countries.

"Maximizing the social and economic benefits of tourism, while minimizing any negative impacts on host communities and the environment, should remain at the forefront of the sector's efforts in the years to come, with policy-makers, companies and travellers all contributing to this overarching and shared objective" $[1$, p. 4]. In the last few years, many states implemented Tourism Strategic Plans or tourist development measures -according to the Mediterranean Action Plan, the European Action Programme for the Environment, or actions fulfilled at Member State or regional level - to ensure that the tourism industry can generate money and jobs, without compromising tourist destination identity and local environment. An increasing number of policy makers understood that tourism is a significant source of income for local economies and a real transformative force for improving millions of lives. The Tourism Strategic Plan is a valuable instrument that aims at ensuring an effective governance for the tourism sector. The challenge is to manage an increasingly number of tourists and a rapidly evolving market following the principles of sustainable development.

This paper is part of a major research project carried out by the authors under a European Project, Alter Eco "Alternative tourist strategies to enhance the local sustainable development of tourism by promoting Mediterranean identity", Interreg MED 2017-2019 [2, 3]. Starting from the analyses of tourism planning and policies across the Mediterranean region, the authors propose an innovative approach that integrates the tourism carrying capacity methodology within Tourism Strategic Plans. Each region in the Mediterranean area, the first tourist destination in the world, should calculate the carrying capacity of its main tourist attractions. The tourism carrying capacity is the maximum number of tourists that can visit, at the same time, a destination without causing negative impacts. The authors propose to include in Tourism Strategic Plans different solutions / actions depending on whether the 
carrying capacity is greater, less or equal to the actual number of tourists who visit a destination daily. Finally, this paper shows how to apply the proposed methodology to a specific case: The Tourism Strategic Plan of the Liguria Region.

\section{TOURISM PLANNING AND POLICIES IN THE MEDITERRANEAN REGION}

For tourism to be sustainable in the future, it is necessary that policies and plans are implemented today. Environmental and social criteria should be integrated into tourism policies and programmes to encourage more responsible business practices. Policymakers, planners must analyse the emerging trends in tourism and define new measures that lead to sustainable growth. At international level, the main objective of tourism policies and planning should be to combine the economic, cultural and social benefits of tourism jointly with people, destinations and countries. International tourism, through adequate policies and plans, has the potential to be one of the most important incentive to improve the local and the global quality of life [4]. "Long-term strategies and policies focused on promoting quality employment and job creation, skills development, entrepreneurship, innovation, effective investment, and integrated regional development, are integral to achieving sustainable and inclusive tourism growth; growth that considers current and future economic, social and environmental impacts, and addresses the needs of visitors, the industry, the environment and host communities" [5, p. 12]. The Mediterranean Region is the principal tourist destination in the world. For this reason, the authors focus their interests on this area by analysing the main policies and plans for tourism in force. Four of the most visited countries in the world border the Mediterranean Sea. France received more visitors than any other country in the world. Following France, in the top 10 international tourism destinations list, Spain holds the number two, Italy the number five ant Turkey the number eight. Greece is also very popular, it is not included in the top ten chart, but annually welcomes more than 27.2 million visitors (Table 1 ).

Table 1. Internationa 1 tourist arrivals, source: UNWTO 2017

\begin{tabular}{ccccc}
\hline \multicolumn{5}{c}{ INTERNATIONAL TOURIST ARRIVALS } \\
FRANCE & SPAIN & ITALY & TURKEY & GRECE \\
\hline 86.9 & 81.8 & 58.3 & $\mathbf{1 . 6}$ & $\mathbf{2 7 . 2}$ \\
million & million & million & million & million \\
\hline
\end{tabular}

In the last five years, these countries have drawn up strategies or plans for tourism development and management (Table 2). These policies are based on sustainability, diversification of tourism products, digital innovation, tourism coordination, quality, training and employment, investments and incentives (Table 3). Despite these common goals, each State has established its own priorities for action [5].

Following the recent terrorist attacks, France and Turkey are working hard to improve security [6, 7]. Greece and Italy state their intentions to focus on actions to enhance tourism mobility. With this in mind, in Italy the Ministry of Culture and Tourism and the Ministry of Infrastructure and Transport signed the "Special Plan for Tourism Mobility" setting common goals with operators and stakeholders to improve mobility for tourism [8]. For France and Italy, accessibility is another key factor to competitiveness in tourism; the tourism offer needs to become accessible to everybody. Among the priorities of the Spanish and Greek plan for tourism there is to encourage research related to tourism: collection of data, collaboration between public authorities and universities, establishment of research centres on tourism $[5,9]$.

Besides these national policies, several layers of regional and local government share the responsibility of boosting tourism. Regions are responsible for the promotion and regulation of tourism within their own territories. Local entities (provinces, metropolitan areas and municipalities) take care of information promotion and dissemination supporting their own tourist interests. This multi-actorgovernance is vital to enhance competitiveness in the tourism sector. Even though in France and Spain there are several examples of plans at the municipal, metropolitan or departmental level, in Italy only the city of Venice has its own policy instrument. The lack of the local level penalizes many Italian destinations that cannot rely on their own strategic plan for a better coordination with regional and national instruments. In Spain, besides Barcelona, the first tourist destination of the country, many other cities have their own Strategic Tourism Plan (Malaga, Cordoba, Valencia, Zaragoza...). In France, only the main metropolitan areas adopted a Strategic Plan for tourism development (Paris and Lyon), but there are several plans made by departmental authorities or union of municipalities. These plans work on a smaller scale than the regional ones and try to meet the needs of tourists while respecting the interests of the residents. Tourism is an engine of growth, to create quality jobs, business and local development opportunities, but local policies are necessary to mitigate the negative impacts on local communities, and better spread the benefits to all people and territories. "In the absence of destination strategy that defines the desired positioning (in relation to the wealth of attractions, the resources available, the desired target of customers and the interests of community), the supply tends to focus on a few things already known to the public, with negative effects on accessibility and quality of the experience of visiting" $[10, p$. 354].

Table 2. National policies and plans for tourism management and development

\begin{tabular}{ccccc}
\hline & NATIONAL POLICIES AND PLANS & TURKEY & GRECE \\
\hline FRANCE & SPAIN & ITALY & The \\
At national level, France implemented a & The National and Integral Tourism & National Strategic & The 2015-19 & The National \\
set of measures during the first Inter- & Plan 2012-15 (Plan Nacional e & Plan for Tourism & Strategic Plan & Strategic Plan \\
Ministerial Council of Tourism (CIT), & Integral de Turismo, PNIT). & 2017-2022 (Piano & of the Ministry & for Tourism \\
held in July 2017. A second CIT took & The Spanish Secretariat is working on & Strategico del & of Culture and & 2014-20 \\
place on January 2018 & a new national strategy & Turismo, PST) & Tourism & \\
\hline
\end{tabular}


Table 3. Main goals of the plans/policies for tourism in Med Countries

\begin{tabular}{|c|c|c|c|c|c|}
\hline $\begin{array}{l}\text { COUNTRIES } \\
\text { OBJECTIVES } \\
\end{array}$ & FRANCE & SPAIN & ITALY & TURKEY & GRECE \\
\hline Sustainability & $\mathrm{X}$ & $\mathrm{X}$ & $\mathrm{X}$ & $\mathrm{X}$ & $\mathrm{X}$ \\
\hline Quality & $\mathrm{X}$ & $\mathrm{X}$ & $X$ & $\mathrm{X}$ & $\mathrm{X}$ \\
\hline Diversification of products & $\mathrm{X}$ & $\mathrm{X}$ & $\mathrm{X}$ & $\mathrm{X}$ & $\mathrm{X}$ \\
\hline Promotion in international markets & & $X$ & $X$ & $\mathrm{X}$ & $\mathrm{X}$ \\
\hline Favour public-private co-responsibility & & $\mathrm{X}$ & $\mathrm{X}$ & $X$ & \\
\hline Digitalisation & $\mathrm{X}$ & $\mathrm{X}$ & $\mathrm{X}$ & $\mathrm{X}$ & $\mathrm{X}$ \\
\hline Addressing seasonality & & $\mathrm{X}$ & $\mathrm{X}$ & $\mathrm{X}$ & $\mathrm{X}$ \\
\hline Security & $\mathrm{X}$ & & & & \\
\hline Tourist Mobility & & & $\mathrm{X}$ & & $\mathrm{X}$ \\
\hline Coordination of the tourist offer & $\mathrm{X}$ & $\mathrm{X}$ & $\mathrm{X}$ & $\mathrm{X}$ & $\mathrm{X}$ \\
\hline Market/tourist-oriented approach & & & $\mathrm{X}$ & $\mathrm{X}$ & \\
\hline Investments and incentives & $\mathrm{X}$ & $\mathrm{X}$ & $\mathrm{X}$ & $\mathrm{X}$ & $\mathrm{X}$ \\
\hline Encouraging research & & $\mathrm{X}$ & & & $\mathrm{X}$ \\
\hline Training and employment & $\mathrm{X}$ & $\mathrm{X}$ & $\mathrm{X}$ & $\mathrm{X}$ & $\mathrm{X}$ \\
\hline Accessibility & $\mathrm{X}$ & & $\mathrm{X}$ & & \\
\hline Carriyng capacity & & & & & \\
\hline
\end{tabular}

\section{INTEGRATING THE CARRYING CAPACITY METHODOLOGY INTO TOURISM STRATEGIC PLAN}

Starting from the analysis of the plans and measures in force in the Mediterranean area, the authors investigate how to develop better policies to assist decision-makers in tourism management. In this section, the authors provide an innovative methodology and realistic solutions to design a favourable course for tourism future. Taleb Rifai, the secretary-general of the UNWTO until December 2017, stated that "Carefully managed, tourism can enliven the cultural heritage, generate new opportunities for local communities, and foster tolerance and respect between peoples and nations". In order to effectively promote and safeguard the cultural heritage, a sustainable approach is crucial. In general terms, a tourist destination is sustainable when it does not exceed its carrying capacity $[6,11]$. According to the UNWTO, the Tourism Carrying Capacity (TCC) is the maximum number of people that may visit a tourist destination at the same time, without causing destruction of the physical, economic, socio-cultural environment and an unacceptable decrease in the quality of visitors' satisfaction. This means that tourism activities are vital and attractive for an unlimited period, without altering the local environment and satisfying stakeholders (tourists, businesses, host communities...). The most general description of carrying capacity assessment dates to the 1960s. "The first school of thought defines tourism capacity by how much tourists can be accommodates before negative impacts start to become observable; the second school of thought however defined capacity as reached when the tourists' themselves see the negative impacts and start to with draw from an area as it no longer satisfies their requirements" [12, p. 51]. The carrying capacity assessment is based on the relationship between the tourism industry, the environment and the local community [13]. However, if the concept of TCC is quite understandable and immediate, its quantification is not so easy. There are a few examples of practical calculations in the literature and there is not a unified or predominant methodology. The TCC assessment requires the identification of a critical threshold beyond which a destination can no longer tolerate additional pressures from the tourism industry. Nevertheless, TCC assessment needs to be regarded more as a management tool and less as a rigid technique, which could lead to the definition of a unique numeric value; furthermore defining tourism carrying capacity needs to take into account the particularities of the tourist destination and the characteristic of the tourist demand [14]. Indeed, there are different types of tourism: cultural, natural, sport, religious..., according to different motivations of the journey. It is important to meet and understand this increasingly diverse and unique demanding to compute the TCC of a tourist destination. Both the private and the public sector could benefit from sustainable tourism. Local authorities protect natural and cultural resources and small companies find new investment opportunities. Consequently, local stakeholders should promote the TCC methodology. To do this, city planners should identify the acceptable impacts on the natural, social and economic environment to ensure that the tourist destination do not suffer unwanted consequences [15].

UNEP -United Nations Environment Programmeintegrated the TCC methodology into spatial planning first. Its ICAM -Integrated Coastal Area Management- programme assists countries to protect marine areas using the TCC to control tourism development in costal destinations [16]. In this paper, the authors propose to introduce systematically the carrying capacity methodology into tourism strategic planning in the Mediterranean area. Med countries all struggle with tourism numbers and many med destinations are considering reducing the number of visitors. According to the authors, regional plans should define (especially for the most visited areas) the best strategies to support sustainable tourism. A previous research defined the contents that a good Sustainable Tourism Action Plan - STAP should have [2]. This plan provides actions in support of Agenda 21 and aims at replacing all the previous planning instruments in the field of tourism. As in the case of the SEAP (Sustainable Energy Plan, introduced in Europe in 2015) the STAP is a specific policy tool designed to promote and enhance sustainable tourism at different levels: national, regional and local. It integrates the expected stages included in the ICAM or UNWTO methodology for tourism strategic planning [17] (Table 4). 
Table 4. ICAM, UNWTO and STAP's guidelines for tourism strategic planning

\begin{tabular}{|c|c|c|c|}
\hline \multicolumn{2}{|c|}{$\begin{array}{c}\text { ICAM } \\
\text { Integrated coastal areas management- }\end{array}$} & $\begin{array}{c}\text { UNWTO } \\
\text { Guidelines for tourism planning }\end{array}$ & $\begin{array}{c}\text { STAP } \\
\begin{array}{c}\text { Sustainable Tourism Action Plan (defined } \\
\text { by the authors) }\end{array} \\
\end{array}$ \\
\hline \multicolumn{2}{|r|}{ 1. Initiation (purpose) } & \multirow{2}{*}{ Basic analysis } & \multirow{2}{*}{ Phase 1. Background } \\
\hline \multirow{5}{*}{ 2. Planning } & Preparatory activities & & \\
\hline & \multirow{2}{*}{ Analyses and forecasts } & Detailed analysis & \multirow{2}{*}{ Phase 2. State of the art diagnostics } \\
\hline & & Synthesis & \\
\hline & Definition of goal and strategies & Goal and strategies & \multirow[b]{2}{*}{ Phase 3. Goals, strategies and main actions } \\
\hline & $\begin{array}{c}\text { Integration of detailed plans and } \\
\text { management policies }\end{array}$ & Plan & \\
\hline \multirow{3}{*}{\multicolumn{2}{|c|}{ 3. Plan implementation, monitoring and assessment }} & \multirow{3}{*}{ Implementation } & Phase 4. Plan implementation \\
\hline & & & Phase 5. Plan monitoring \\
\hline & & & Phase 6. Awareness / participation \\
\hline
\end{tabular}

Table 5. Integration of the CCA into the STAP at the regional level

\begin{tabular}{|c|c|}
\hline SUSTAINABLE TOURISM ACTION PLAN & TOURISM CARRYING CAPACITY METHODOLOGY \\
\hline $\begin{array}{c}\text { Phase 1. BACKGROUND } \\
\text { - problems related to territorial tourism } \\
\text { management } \\
\text { - European and national tourism legislation and } \\
\text { local policy } \\
\text { - specific goals for the analyzed territory } \\
\text { - working groups/forum }\end{array}$ & $\begin{array}{c}\text { INVESTIGATION PHASE AND MAPPING PHASE } \\
\text { Analysis of the current tourist scenario: } \\
\text { - boundaries of the tourist area (Region) } \\
\text { - tourist facilities (hotels, restaurants, tourist agency) } \\
\text { - main tourist attractions } \\
\text { - number of visitors } \\
\text { - tourist destination in development } \\
\text { - tourism industries, employment and complementary indicators }\end{array}$ \\
\hline $\begin{array}{l}\text { Phase 2. DIAGNOSTIC OF THE STATE OF } \\
\text { THE ART } \\
\text { - status quo } \\
\text { - data collection } \\
\text { - goals evaluation } \\
\text { - SWOT analysis } \\
\text { - PEST analysis }\end{array}$ & $\begin{array}{c}\text { ANALYSIS PHASE } \\
\text { - tourist destination and tourist offer analysis } \\
\text { - relationship between the tourist destination and the global tourist offer } \\
\text { - tourism impacts assessment } \\
\text { - tourist demand } \\
\text { - alternative paths and solutions }\end{array}$ \\
\hline \multirow{2}{*}{$\begin{array}{c}\text { Phase 3. PLANNING PART } \\
\text { - planning conditions } \\
\text { - identification of actions/best practices for } \\
\text { sustainable tourism } \\
\text { - goals determination } \\
\text { - links with other programs in force } \\
\text { - actions, time, actors and budget determination }\end{array}$} & $\begin{array}{c}\text { TCC ASSESSMENT } \\
\text { - parameters and constraints definition } \\
\text { (environmental, economic, social, cultural) } \\
\text { - weighted constraints according to the tourist destinations } \\
\text { - Linear Programming or Fuzzy Goal Linear Programming model }\end{array}$ \\
\hline & $\begin{array}{c}\text { TOURIST STRATEGY } \\
\text { - alternative scenarios } \\
\text { - scenarios assessment } \\
\text { - sustainability indicators identification } \\
\text { - new strategies depending on whether the carrying capacity is greater, less or equal to } \\
\text { the actual number of tourists who visit a destination daily }\end{array}$ \\
\hline $\begin{array}{l}\text { Phase 4. PLAN IMPLEMENTATION } \\
\text {-strategies and good practices to support } \\
\text { sustainable tourism }\end{array}$ & \multirow{2}{*}{$\begin{array}{l}\text { IMPLEMENTATION, MONITORING AND ASSESMENT } \\
\text {-pre-feasibility studies } \\
\text { - plan implementation } \\
\text { - plan monitoring and assessment } \\
\text { - dissemination }\end{array}$} \\
\hline $\begin{array}{c}\text { Phase 5. PLAN MONITORING } \\
\text { - identification of specific indicators }\end{array}$ & \\
\hline $\begin{array}{l}\text { Phase 6. AWARENESS / PARTICIPATION } \\
\text { - this last phase is transversal to the previous ones } \\
\text { considering the importance of participation }\end{array}$ & $\begin{array}{c}\text { COMMUNITY PARTICIPATION STARTS } \\
\text { - forum with stakeholders (local authorities, business sector, host community, etc.) }\end{array}$ \\
\hline
\end{tabular}

In particular, this paper focuses on the integration of the carrying capacity methodology into the STAP at regional level. The TCC should be included in every stage of the STAP (Table 5). The calculation of the TCC is carried out within the planning phase, but preparatory activities are essential to get information and data to compute the maximal number of tourists. It is also important to establish quantitative - the number of beds in hotels, parking facilities... - and qualitative parameters, such as social or environmental impacts, to solve the most used systems to calculate the TCC: The Linear Programming model or the Fuzzy Goal Linear Programming model (Table 6), [3].

Starting from the analysis of the TCC results, the Tourism Strategic Plan should identify new measures and policies to support sustainable tourism. After reviewing the existing literature, the authors determinate three different types of actions depending on whether the carrying capacity is greater, less or equal to the actual number of tourists who visit a destination daily $[14,16,18]$ :

- red case: this case is not sustainable, the number of tourists exceeds the threshold established by calculating the TCC. This means that there are too many people in a particular place at a particular time. In "red" destinations, tourism creates more problems than benefits. There are evident negative impacts on the local natural, social and cultural environment such as social dislocation, loss of cultural heritage, economic dependence and ecological degradation;

- orange case: The "orange destinations" are far from the 
carrying capacity limit. It is still possible to develop sustainable tourism in order to generate economic, social and cultural positive effects;

- green case: the number of tourists is close to the threshold suggested by the TCC assessment. In "green" destination, tourism respects both local people and cultural, environmental heritage. The tourism industry is well developed, but it is important to continue to manage it correctly.

For each case (red, orange and green), the authors recommend some corrective measures and actions (Table 6) to be included in the Regional Tourism Plan or in the new STAP to promote sustainable tourism. Some destinations have a greater number of visitors than the maximum carrying capacity, while others have a similar or much lower value. For each case, the Regional Tourism Plan should report some prescriptions and actions at the regional or municipal level. An effective Regional Tourism Plan should provide guidelines to achieve acceptable levels of sustainability in all tourist destinations.

Table 6. Strategies according to the TCC index to be included in the STAP at regional level

\begin{tabular}{|c|c|}
\hline \multicolumn{2}{|c|}{$\begin{array}{l}\text { Constraints: HB number of beds in hotels; NHB number of beds in extra-hotels/non-hotels; L number of places to eat; P parking facilities; } \\
\text { TR public transport capacity; WD solid waste capacity; SMW max number of people allowed inside the main attraction/square } \\
\text { The constraints make it possible to calculate the inequality needed to solve the linear programming problem. }\end{array}$} \\
\hline Carrying capacity assessment & Recommended actions and strategies \\
\hline \multirow[b]{4}{*}{$\begin{array}{l}\text { Over the carrying capacity limit: } \\
\text { full saturation } \\
\text { RED CASE }\end{array}$} & To draft a Tourism Strategic Plan at the local level (compulsory) \\
\hline & To reduce day visitors and increase their daily expenditure \\
\hline & $\begin{array}{c}\text { To find corrective measures to reduce the number of tourists or to increase the carrying capacity acting } \\
\text { on the constraints }\end{array}$ \\
\hline & $\begin{array}{l}\text { To start a consultative or participative process where local public authorities, representatives of the } \\
\text { tourism industry, local communities, university and private company jointly design sustainable } \\
\text { strategies for tourism development }\end{array}$ \\
\hline \multirow[t]{4}{*}{$\mathrm{TCC}<$ of the daily $\mathrm{n}^{\circ}$ of visitors } & $\begin{array}{l}\text { To establish special agreements with tour operators and representatives of the tourism industry } \\
\text { (accommodation and restoration sector) }\end{array}$ \\
\hline & To create public-private partnerships to promote sustainable tourism development \\
\hline & Smart technologies for tourist arrival management \\
\hline & Alternative routes should be considered to disperse tourism economic benefits to marginal areas \\
\hline \multirow{3}{*}{$\begin{array}{l}\text { Far from the carrying capacity } \\
\text { limit } \\
\text { ORANGE CASE } \\
\text { TCC > of the daily } n^{\circ} \text { of visitors }\end{array}$} & $\begin{array}{l}\text { New destinations will compete to maximise the visitor expenditure in their region. However, that } \\
\text { competition will take place within a collaborative framework that ensures the best overall outcome for } \\
\text { the Region }\end{array}$ \\
\hline & In the case of smaller or less well-developed destinations, it is important to cultivate emerging markets \\
\hline & Define new measures to develop this tourist attraction \\
\hline \multirow{4}{*}{$\begin{array}{l}\text { Close to the carrying capacity } \\
\text { limit: intensive and moderate. } \\
\text { GREEN CASE } \\
\text { TCC }=\text { of the daily } \mathrm{n}^{\circ} \text { of visitors }\end{array}$} & Facilitate tourism investment into infrastructure and attractions \\
\hline & To draft a Plan for tourism at the local level (if it is possible) to support sustainable tourism \\
\hline & $\begin{array}{l}\text { All stakeholders and partners must work in a collaborative and integrated way to focus on destinations } \\
\text { and achieve an impact at the industry level }\end{array}$ \\
\hline & $\begin{array}{l}\text { Ensure that the growth of visitors is in harmony with the community, the environment and the } \\
\text { destination commitment to responsible tourism }\end{array}$ \\
\hline
\end{tabular}

\section{CASE STUDY: A NEW APPROACH FOR THE PLAN FOR TOURISM OF THE LIGURIA REGION}

The Liguria Region wants to gain a foothold in the global tourism market. On 26 July 2017 the Regional Council approved the "Plan for tourism 2020" to guide the tourism industry through a period of expansion in visitation and expenditure. Tourism in Liguria accounts for $7.8 \%$ of the regional GDP, generating more than $10 \%$ of the workforce. In 2016 , tourism grew both in terms of tourist numbers and arrivals with a growth rate of $4.35 \%$. In the last 15 years, Liguria has transformed its offer improving the range of tourism products and services. It used to be only a seaside destination, but now it is enhancing its cultural, sport, gastronomic and MICE (Meetings, Incentives, Conferences and Exhibitions) offer. The regional plan considers the objectives established by the National Strategic Plan for Tourism for the period 2017-2022 (Piano Strategico del Turismo - PST - prepared by the Standing Committee on Tourism Promotion, with coordination by the Directorate General of Tourism of the Ministry of Heritage, Cultural Activities and Tourism - MIBACT). The PST, by proposing new destinations, relaunches Italy's leadership on the world market and acknowledges sustainable and high-quality tourism as a driving force for economic wealth and social wellbeing. It offers the opportunity to implement in full the strategy of providing Italy with a unified vision of tourism and culture, thus satisfying the need to focus the country's development policies on tourism [8]. The National Plan for Tourism is a governance tool that coordinates central administrations, regions and territories in tourism management. The Liguria Region adapted the strategic 
objectives of the PST to specific territorial characteristics designed through a structured dialogue with local stakeholders. Key issues and challenges for Liguria are: strengthening the region's international position; combating seasonality; improving the quality of tourism offer in order to increase the average spending of tourist per day; improving competitiveness in the region; boost tourism promotion in order to contribute to the diversification of markets and increase development and growth of the sector; ensuring continued provision of high-quality visitor experiences.

The regional plan is organized in five sections. The first one reports the legislative framework -according to the provisions of PST-, the main objectives of the plan and the working group names. The second section is devoted to the analysis of thestate-of-the-art. It criticizes the previous strategy included in the plan for tourism for the period 2013-2015. This section contains an interesting SWOT (Strengths, Weaknesses, Opportunities, Threats) analysis relating to tourism industry development in Liguria. The plan makes no mention of the difficulties many overcrowded destinations are facing. Great emphasis has been placed from a promotional perspective on extending the regional offer away from major attractions towards the diversity and plurality of landscapes and destinations. The following two sections describe the vision, the mission and the strategies promoted by the regional council.
Four strategic axes have been identified: tourism products, marketing, governance and hospitality. Liguria takes on a new and innovative approach with the aim to become a multiproduct and experiential destination. Unlikely the plan does not include sustainability or consider the bad impacts related to tourism even if some destinations are complaining about the sheer pressure of tourist numbers. The final section explains how to implement the plan (budget, timing, monitoring assessment...) over the next five years.

The authors apply the methodological approach, described in section 3, to the Plan for Tourism of the Liguria Region. The aim is to encourage sustainable tourism by limiting all the negative effects caused by uncontrolled and mass tourism. The TCC assessment is a powerful tool for enhancing sustainability. Regional planners should compute the TCC of the main tourist attractions in Liguria. After that, they have to identify specific corrective measures depending on whatever these attractions fall within the red, orange or green case. By way of explanation, the authors compute the TCC in three different areas (Figure 1) and provide different remedial actions according to their levels of tourism sustainability:

- Cinque Terre: red level (un acceptable)

- Nervi: orange level (barely acceptable)

- Historic center of Genoa: green level (acceptable)

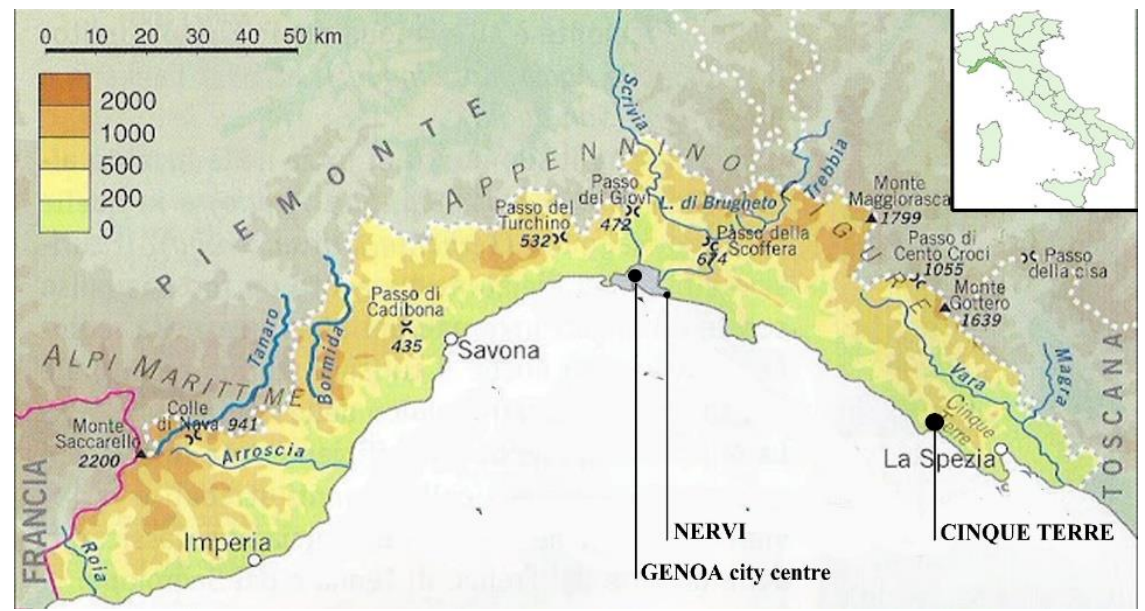

Figure 1. Case studies examined by the authors

The first case analysed by the authors refers to Cinque Terre. "For at least five years, Cinque Terre has had to deal with an impressive tourist performance: three million visitors every year. An assault that brings much wealth yet also many questions, most of them still unresolved, especially on how to regulate it" $[18$, p. 1]. The Cinque Terre are characterized by a wonderful landscape, but they are small and surrounded by a fragile territory that can barely support the two million visitors a year. To move from one village to another, visitors must take the train because there is no road connection. This is leading to an unsustainable situation where trains and railway stations are too crowded. The case of the city centre of Genoa is different. Genoa is the Capital of Liguria Region, with its 592,507 inhabitants, is the sixth largest city in Italy and the third city in the Northern Italy. The historic centre of Genoa is one of the largest in Europe, it unwinds in an intricate maze of alleyways that open unexpectedly onto small squares; the soul of the city lives here in these alleyways, where smells, tastes, and cultures have combined throughout history. The last case analysed is Nervi, a district of Genoa about $1 \mathrm{~km}$ far from the city centre with a population of 10.903 at the 2014 census. It is a former fishing village famous for its sea promenade $(2 \mathrm{~km}$ walkway along the costa rocciosa a picco sul mare), its big natural park and its museum hub (Galleria d'arte moderna in Villa Saluzzo Serra, The Raccolta Frugone in Villa Grimaldi Fassio, The Luxoro Museum and the Wolfsoniana Museum). The ancient harbour, Porticciolo, is the historical hearth of Nervi.

Analysing the results related to the level of sustainability (according to the tourism carrying capacity assessment) of the tourist destinations under study, three different cases emerged. For each case, the authors identified some corrective measures that should be included in the Liguria Region's plan for tourism to improve tourism sustainability levels (Table 7). All the suggested actions aim at managing tourism in a greener way. Tourism has a great potential if it is well-planned, otherwise it becomes a threat. The results of the planning phase demonstrate that it is important to define a Tourism Strategic Plan for all the three areas under study to promote sustainable policies and actions. 
Table 7. Guidelines for the new tourism plan of the Liguria Region (extract)

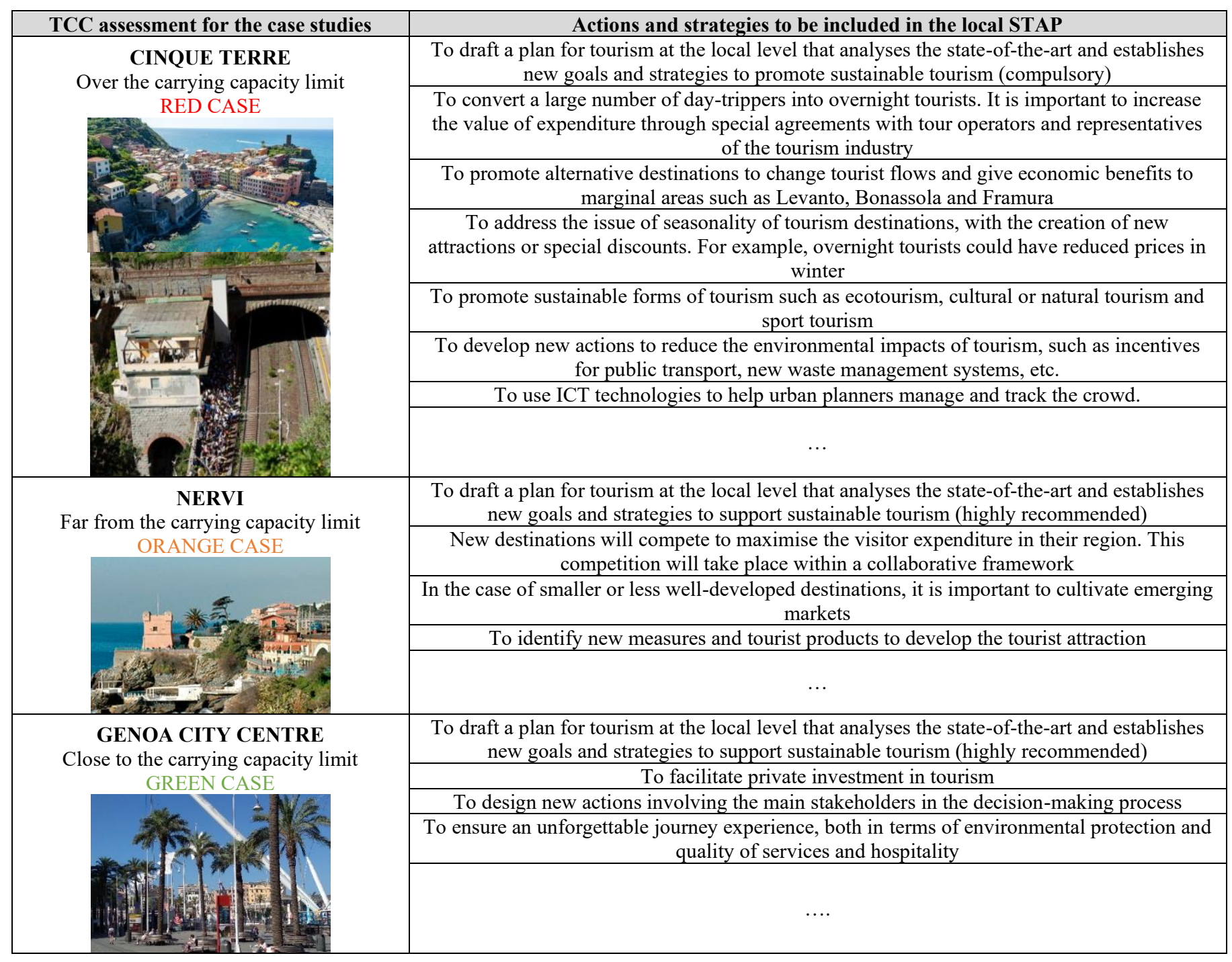

The tourist load of the Cinque Terre is more than double if compared to the limit calculated to ensure sustainable tourism. This territory has high naturalistic value; it is very attractive for tourists on the one hand and very fragile on the other. Local authorities should design urgent and drastic interventions to limit the number of tourists, and consequently to reduce the moments in which it is exceeded the TCC limit. For these reasons, it is not enough to have a regional plan; a local planning instrument is needed. In this area, it is essential to fight against seasonality extending the tourist season. The most common actions, to change the seasonal pattern of tourism, are: reducing prices charged for accommodation and services in the months immediately before and after the peak season and creating new attractions throughout the year.

Most of the visitors who go to the Cinque Terre are daytrippers, who leave little or nothing to these villages. Overnight tourists are better since their average expenditure per day tends to be three times greater. Cruise ships generate the majority of day-trippers. Therefore, to contain the number of tourists and to not exceed the TCC it is essential to manage of cruise passenger arrivals. In the last five years, the cruise ship load at the Cinque Terre has increased exponentially: in 2013214,000 tourist arrivals were recorded and in 2017 this popular destination exceeded 667,000 arrivals. To reduce daytrippers' impacts it would be important to avoid the presence in the port of La Spezia of more than one/two cruise ships at the same time. Moreover, cruise companies could offer the possibility to visit alternative destinations. Local and regional authorities should directly recommend to cruise-operators other interesting areas. To help city planners, the authors identified several alternative routes close to the Cinque Terre: the nearby village of Lerici, the natural park of Montemarcello, the Palmaria Island - designated by UNESCO as a World Heritage Site -, Levanto, Bonassola and Framura. These destinations can be visited all over the year. In the winter there is a wide offer of historical and cultural sites: beautiful churches (as the church of St. Andrew the Apostle - built in 1222 in typical Ligurian style with black and white stripes), castles and medieval villages. In the summer, these destinations are a paradise for nature trails, water sports, racing cyclists and sea tourism. In the spring and summer season Levanto is connected to the Cinque Terre also by sea thanks to a small ferry.

Overtourism not only affects local natural, economic and social environment, but also visitors. Tourists who came in such large numbers that they spoiled the place they were meant to enjoy. They threatened what attracted them in the first place: the tranquillity of the Ligurian Riviera. A good plan for tourism should promote measures to cut drastically the number of visitors in critical destinations. Nevertheless, local authorities wish to introduce limitations on the number of tourists as a last resort. Generally, other corrective measures 
are preferred. For example, ICT technologies can help urban planners manage and track the crowd. There are different tools that monitor, measures, analyse and model the flows of visitors to the different destinations. The aim is to provide objective, empirical, real-time geo-referenced data that will allow local authorities to understand the consumption patterns of destination visitors during the year. Thanks to these data, it is easier to coordinate arrivals and to avoid seasonal peaks.

According to the results obtained, the city centre of Genoa is not normally exceeding its carrying capacity. An exception was registered last year during Easter break: in Genoa city centre there were more than 23.300 tourists because there were 5 cruise ships in the port with about 4.000 passengers for each. Considering these data, in order to safeguard the Mediterranean identity of Genoa, the access of cruise ships into the port should be regulated and a Plan to support sustainable tourism is needed [19]. In this case, the STAP should define measures to moderate the growth tourist arrivals, increase regional dispersion, reduce seasonality, and better manage visitor flows at popular tourist sites.

Nervi is a long way from reaching its carrying capacity, therefore the Plan for Tourism should suggests actions to foster this tourist destination. It is important to launch a new branding campaign over the next years for global marketing, set up interactive advertising in touristic sites and develop local tourist offers. For this reason, in 2018 five different tourist products have been tested to immerse the tourist in the natural harmony of Nervi. These products were developed thanks to a European Project, Alter Eco "Alternative tourist strategies to enhance the local sustainable development of tourism by promoting Mediterranean identity", Interreg MED 2017-2019. The authors helped the Municipality of Genoa define the general strategy to promote Nervi in order to guarantee all visitors a quality offer and experience. Five alternative tourist products have been design involving in decision-making processes many local stakeholders, such as NGO, residents and professional associations, with the aim of creating and promoting an attractive, intelligible offer for national and international audiences. Tourists discover the village of Nervi and its stunningly beautiful landscapes participating in: a guided walking tour through the beauties of Nervi -from the marina along the promenade overlooking the sea, up to the Parks and the Museums-; an olfactory walking tour through the Museums and the Parks; two experiential workshops to learn about ancient crafts and trades traditionally linked to sea-life and to the growing of local products; outdoors activities such as kayak excursions and scuba diving.

\section{CONCLUSIONS}

When a destination exceeds its tourism carrying capacity, there are different corrective measures that can be taken into consideration. In the literature, many researchers agree that "if degradation occurs, then management actions are implemented to return the area to within its numeric carrying capacity" [20, p. 293]. According to the authors, other solutions could be taken to separate the carrying capacity concept from the use of restrictive policies/measures (such as gates to reduce tourist numbers or pre-selling tickets to limit tourist arrivals). For example, it is possible to increase the carrying capacity of a tourist destination, acting on the constraints used for the TCC assessment: number of beds in hotels or in extra-hotels; number of places to eat; parking and waste facilities; public transport capacity; max number of people allowed inside the main attraction/square. Therefore, public authorities could increase the carrying capacity value improving local accommodation facilities or waste sustainable management.

The tourism carrying capacity is a dynamic and effective approach. It can be easily adapted to specific situations supporting sustainable tourism development. Integrating this approach in the field of spatial planning, the authors highlighted that the TCC is not only a tool to analyze the stateof-the-art of a tourist destination, but also as objective parameter to enhance sustainability. As demonstrated by the application to the Ligurian case -described in the previous section-, local and regional authorities can develop guidelines, strategies and corrective measures using the TCC methodology striking a good balance between economic benefits and social-environmental costs. The methodology proposed could be easily extended to the international context. Worldwide many destinations are struggling to cope with the mass influx of visitors. Overtourism is affecting residents in the course of their normal life and is damaging the natural and social environment. The paper focus on Mediterranean Countries where the negative effects of tourism are more evident. Across southern Europe protests and social movements against the tourism industry are growing in number. However, the TTC assessment could help policy makers, from all over the world, manage tourism in a sustainable way.

\section{REFERENCES}

[1] World Tourism Organization. UNWTO Annual Report 2017. Madrid: Published by the World Tourism Organization (UNWTO), 2018. https://www.eunwto.org/doi/book/10.18111/9789284419807.

[2] Pirlone, F., Spadaro, I. (2017). Sustainable tourism action plan in the Mediterranean coastal areas. International Journal of Sustainable Development and Planning, 12: 995-1005. https://doi.org/10.2495/SDPV12-N6-995-1005

[3] Candia, S., Pirlone, F., Spadaro, I. (2018). Sustainable development and the plan for tourism in Mediterranean coastal areas: Case study of the region of Liguria, Italy. WIT Transactions on Ecology and the Environment, 217: 523-534. https://doi.org/10.2495/SDP180461

[4] Edgell, D.L., Swanson, J.R. (2013). Tourism Policy and Planning: Yesterday, Today and Tomorrow. $2^{\text {nd }}$ edition, New York: Routledge.

[5] Organisation for Economic Co-operation and Development. OECD Tourism Trends and Policies 2018. Paris: OECD Publishing, 2018. https://www.oecd.org/cfe/tourism/2018-TourismTrends-Policies-Highlights-ENG.pdf.

[6] Interministerial Council for Tourism. The Governament's roadmap for tourism. Paris: Matignon Press Office, 2017.

[7] UKEssays. November 2018. Tourism Policies and Plans in

https://www.ukessays.com/essays/tourism/tourismpolicies-plans-turkey-9773.php?vref=1, accessed on Sep. 20, 2018.

[8] Ministero per i beni e le attività culturali. Strategic plan for Tourism 2017-2022. Rome: MiBACT Publishing, 
2017.

[9] Instituto de Turismo de España (Turespaña). Plan Nacional e Integral de Turismo 2012-2015. Madrid: Ministerio de industria, energía y turismo, 2012.

[10] Lamb, D. (1988). Tourism development and planning in Australia: The need for a national strategy. International Journal of Hospitality Management, 7(4): 353-361. https://doi.org/10.1016/0278-4319(88)90046-1

[11] O'Reilly, A.M. (1986). Tourism carrying capacity: Concept and issues. Tourism Management, 7(4): 254258. https://doi.org/10.1016/0261-5177(86)90035-X

[12] Ajay, K.L., Devasia, D., Kumar, S. (2015). The social perspective of tourism in review of sustainability and carrying capacity: A synthesis of observations and convictions. Atna - Journal of Tourism Studies, 10: 4558. https://doi.org/10.12727/ajts.14.4

[13] G. Mc Intyre, Sustainable Tourism Development: Guide for Local Planners, Oslo: Unipub, 1993.

[14] Coccossis, H., Mexa, A. (2004). The Challenge of Tourism Carrying Capacity Assessment. London:
Routledge Taylor and Francis Group.

[15] McCool, S.F., Lime, D. (2001). Tourism carrying capacity: Tempting fantasy or useful reality? Journal of Sustainable $\quad$ Tourism, 9(5): 372-388. https://doi.org/10.1080/09669580108667409

[16] UNEP. Guidelines for Carrying Capacity Assessment for Tourism in Mediterranean Coastal Areas, Split: Priority Actions Programme Regional Activity Centre, 1997.

[17] UNEP. WTO, Making Tourism more sustainable, A guide for policy makers, Madrid: World Tourism Organisation and United Nation Environment Programme, 2005.

[18] PAP/RAC. Guide to Good Practice in Tourism Carryng Capacity Assesment, Split: Priority Actions Programme Regional Activity Centre UNEP, 2003.

[19] Menduni, M. (2018). Cinque Terre, Italy's ongoing battle against rude tourists. La Stampa.

[20] Mohammad, M., Al Mamun, A., Mohammad, Z., Malekur, R. (2013). Ecotourism carrying capacity. Journal of Forest Science, 29(4): 292-299. 